\title{
Malesia Bryophytes Diversity
}

\author{
Ferdinand Susilo1, Muhammad Komarul Huda ${ }^{2}$, Hanifah Mutia Z.N. Amrul ${ }^{3}$ \\ ${ }^{1}$ Biology Study Program in Biology Faculty, University of Medan Area, Medan, Indonesia \\ ${ }^{2}$ Biology Study Program, University of Simalungun, Pematangsiantar, Indonesia \\ ${ }^{3}$ Agrotechnology Study Program in Science and Technology Faculty, University of Pembangunan Panca Budi, \\ Medan, Indonesia \\ zulfikar@staff.uma.ac.id
}

\begin{abstract}
Bryophyte is a division of plants that lives on land, generally it is green and reproduces through spores, has ecological and economic functions, and plays an important role in forest ecosystems. It spreads out almost in all parts of the earth with different characters in each group. It is divided into 3 groups, namely liverwort, true moss, and hornwort, which are phylogeny and true liverwort is in the same lineage. The number of bryophytes species is around 18000 with the largest distribution area of bryophyte diversity in tropical and subtropical latitudes, such as the Malesia region which includes Malaysia, Indonesia, Timor Leste, Papua New Guinea, the Philippines, and Brunei. Various studies were carried out related to the diversity of bryophyte, especially in the Malesia region, and found various types including new species, new records, and new characters.
\end{abstract}

Keywords: malesia; briophyte; diversity

\section{Introduction}

Bryophyte is a non-vascular plant, small in size, undergoing a life cycle that alternates between haploid and diploid generations with a more dominant gametophyte phase (Gradstein, S. R., Churchcill and Salazar, 2009). Taxonomically, it are divided into three groups namely Marchantiophyta (liverworts), Briophyta (true mosses), and Anthocerotophyta (hornworts) (Cole and Hilger, 2016).

It spreads throughout the world, from the poles and alpine to the tropics with a number of species ranges from 18000 (Cole and Hilger, 2016). The greatest diversity of bryophytes exists in tropical and subtropical latitudes, such as the Malesia region which is a biogeographic region stretching across the Equator along with the boundaries of the Indomalaya and Australasian ecozones included Malaysia, Indonesia, Timor Leste, Papua New Guinea, the Philippines, as well as Brunei. The Malesia region is divided into: (1) Sundaland (western part) consists of the Malay Peninsula and islands in Sumatra, Java, Bali and Borneo; (2) Philippines, include the Philippine islands which are part of the Indomalaya ecozone; (3) Wallacea, consists of Sulawesi and other large islands, namely Lombok, Sumbawa, Flores, Sumba, Timor, Halmahera, Buru, Seram, and many other small islands; (4) Sahulland, includes the Solomon Islands, Papua New Guinea and the Bismarck Islands. The eastern end of the region includes Papua and the Aru Islands (Brummitt, 2001).

Bryophyte is an important role in forest ecosystems, functions as a pioneer plant, water storage, moisture maintenance, as a substratum for epiphytic species habitat and shelter for several small animals (Bishler-Causse, 1989; Glime, 2007a, b; Gradstein, 2011; Ho, 2013). Other important values of it are as bioindicator and biocontrol (Dymytrova, 2009) (Shen et al., 2010) (Xie, Chun-Feng, 2009) (Govindapyari et al., 2010) and medicinal ingredients (Shen et al., 2010) (Ludwiczuk, Agnieszka, 2008) (Dey and Nath De, 2011).

The existence of it functions ecologically, economically and germplasm sources are inseparable from various threats and disturbances. Most of the forests in the world, especially tropical forests in the Malesia region as a place to grow and develop, it gets severe pressure that threatens their diversity. Deforestation for construction, industry and plantations has a 
negative impact on it and takes away the living rights of it namely epiphytic. Direct and indirect physical disturbance of the soil by using machinery for agricultural purposes, the use of excess fertilizers, herbicides and pollution from industry further worsen the living conditions of it.

This paper discusses and provides information about the diversity of species of it found in the Malesia region in particular.

\section{Discussion}

\subsection{Bryophytes Diversity}

Bryophyte is divided into three groups namely liverworts, true moss (Musci), and hornworts. By observing from cell ultrastructure and molecular biology, bryophyte has three separate evolutionary patterns that has been named Liverwort (Hepaticopsida), Moss (Bryopsida) and Hornwort (Anthocerotopsida) (Sheffield, 2001). Classification of moss is based on morphological forms which then develop at the level of molecular cells and DNA (Shaw and Renzaglia, 2004).

\section{a. Liverwort}

Liverwort has a number of species ranges from 5000 species included in 141 genera and 59 tribes (Singh, 2001;(Cole and Hilger, 2016). It is divided into leafy and breathless liverwort. Leafy liverwort is represented by nearly $85 \%$ of its species which show a great amount of morphological, anatomical and ecological diversity. Plants with leafy shoot systems are the most common form of growth in this class, for example Cololejeunea, Frullania, Jubulopsis and Radula. Thalloid liverwort such as the Metzgeria and Marchantia genus are widespread in semi-aquatic, humid, shady, and terrestrial places, especially in the highlands, sub-alpine and wet climate forests. Sporophyte of liverwort grows in the body of gametophyte until the capsules are ready to grow. Spores are spread out by twisting elater motion and by dividing sporophytes into four segments.

\section{b. True Moss}

True moss has the greatest species diversity with an estimated number of species ranges from 13000 (Cole and Hilger, 2016). It is one of the dominant plant communities in the highlands that grows in humid and cold conditions (Groombridge, Brian, Martin D. Jenkins, 2002). The leaves are generally arranged in a spiral and usually have leaf veins. Capsules have a unique structure called peristom which is very effective for spore distribution. One of the most important groups of it ecologically and economically is Sphagnum (Gairola, Semwal and Uniyal, 2014).

\section{c. Hornwort}

Hornwort consists of about 200 species in the world (Budke et al., 2018); (Cole and Hilger, 2016). Bryophyte of this class is similar to some liverwort, differ from only in thalloid gametophyte in the form of discs and chiseled edges. It has algae colonies namely Nostoc in the middle of the thallus. These algae show the symbiotic nature of providing organic nitrogen for thallus metabolism, while the thallus itself provides food (carbohydrates) and shelter. Bryophyte of this type has sporangia like a cylindrical horn (sporophyte). Released spore from sporophytes takes place gradually over a long period of time and is spread by the movement of water. Hornwort is different from all other land plants because it only has one large chloroplast, like algae in each thallus cell.

\subsection{Phylogeny of Bryophyte}

In principle, bryophyte and vascular plant come from the same ancestors, as well as liverwort, true moss, and hornwort which come from the same ancestors. Based on the 
phylogeny of bryophyte (Cole and Hilger, 2016). Marchantiophyta (liverwort) and Bryophyta (true moss) are in the same group because they have seta, whereas Anthocerophyta (hornwort) has no seta. In other words, liverwort and true moss are in the same lineage that is in the Setaphyta group. The Marchantiophyta group is represented by 14 orders with the largest order being Jungermaniales with 15 families, followed by Marchantiales with 13 families. True mosses is represented by 28 orders with the largest order, namely Hypnales with 19 families. Anthocerophyta is a group of mosses which has the smallest number of species compared to the other two groups and only consists of 5 orders and 4 families.

In the group of liverwort, the presence of caliptra and bud are the basis for grouping at a higher level. Class / subclass in liverwort that do not have calipers and buds are represented by Marchantidae, Pelliidae, Metzgeridae, and Jungermannidae (12 orders). Whereas those with bud calipers do not have classes / subclasses and are directly represented by 2 orders, namely Treubiales and Haplomitriales. Metzgeridae and Jungermannidae originate from one lineage which is further differentiated based on the characters / characteristics: (1) finely or beaded, leaves come from 3 main initials for Metzgeridae; and (2) in the form of leaf blades, leaves originating from the 2 main initials for Jungermannidae.

True moss consists of 8 classes/subclasses namely Buxbaumiidae, Diphysciidae, Gigaspermiidae, Funariidae, Timmidae, Dicranidae, Bryidae, and Hypnanae. This grouping is based on several morphological characters, include: (1) acrocarpus; (2) kladocarpus; (3) artrodontus; (4) hydroid peristom; (5) haplolepid peristom; (6) peristom diplolepidus alternate; (7) Bryum-type peristom; (8) protonema; (9) filaments in chloronema and caulonema; (10) pleurocarpid and pleurocarpid nuclei; (11) pleurocarpus; (12) prosenkimatous leaf cells; and (13) asexual reproduction with deciduous leaves or branch tips, or stagnant gemma (Cole and Hilger, 2016).

\subsection{Habit and Habitat of Bryophyte}

Generaly, bryophyte is smaller in size compared to most other vascular plants. Dawsonia superba is a moss with the highest body size reaches $70 \mathrm{~cm}$. Polytrichum commune generally lives in wet habitat with a body size of up to $50 \mathrm{~cm}$. Other mosses such as Meteoriopsis spp. and Fontinalis spp. can grow to more than 1 meter. Some of them are quite small and can only be seen under a microscope, such as Cephaloziella, Ephemerum and Micromitrium.

Bryophyte is an important component of temperate and tropical forests, found in forms such as carpets on moist soil, large stones, living wood and dead wood, on tree branches, and on leaves. The distribution of them is first influenced by microclimate factors, such as rainfall and temperature, latitude and altitude (Sveinbjörnsson, B., 1992) and by micro environmental conditions such as shade, humidity, humus and temperature (Alpert, 1991). Its vegetation can be influenced by side factors, for example, soil age, rock, forest soil composition, water content (Sillett and Neitlich, 1996) and by substrates such as pH and humus status (Batty, K., J. W. Bates, 2003).

Furthemore, bryophyte grows in terrestrial areas and some are epiphyte. Teresterial bryophyte has the main characteristics to grow in certain habitats such as rocks, bark, wood and decaying stumps, in which soil has moisture, humus and appropriate $\mathrm{pH}$. The carpet of it on the forest floor provides a suitable substratum for seed germination and growth of highlevel seedlings. Many species of them that live in water (aquatic) such as Sphagnum and Riccia fluitans, and some saprophytes such as Buxbaumia and Cryptothallus, which generally grow on dead organic matter. The special character of them is that they absorb water in a short time and become fresh when they are dried under unfavorable conditions (Gairola, Semwal and Uniyal, 2014). 
Epiphyte bryophyte is found in tropical rain forests that contain a lot of water and nutrients, sticks on the surface of the bark, branches and twigs. It grows together with other vascular plants in certain moist areas with nutrients rich in soil. However, in arid and semiarid regions, it will survive in the form of protonema (one of the stages in the life cycle of bryophyte), rhizoidal and gemma bulbs, or the apical part of gametophore. Some species with specific characteristics also grow in saltwater habitats. Moreover, it looks like the Sphagnum type that is able to modify its environment and thus affects the lives of other organisms.

\subsection{Ecology and Benefits of Bryophyte}

Bryophyte plays an important role in an ecosystem, especially in terms of: (a) soil stabilizers because it is very effective in binding soil and trapping nutrients; (b) ability to tolerate dry conditions because it has a high water holding capacity; (c) the formation of wet and moist soils by arranging a spread of moss above the soil surface so that it helps the growth of other vascular plant seeds; (d) filtration of falling water and runoff through moss beds on the ground and peat using a cation exchange system.

Many species of it has the ability to withstand drought, ice and nutrient scarcity. It beds providess the best living space for small animals (invertebrates) to shelter, takes shelter, and looks for food. Some types of lichens can improve nitrogen through the formation of Lichen and it associaties in symbiosis with cyanobacteria (Gairola, Semwal and Uniyal, 2014).

Furthermore, it absorbs mineral elements directly from the atmosphere, for example Sphagnum which accumulates nutrients directly from the atmosphere in its living cells (Osvaldo E. Sala1,*, F. Stuart Chapin , III2, Juan J. Armesto4, Eric Berlow5, Janine Bloomfield6, Rodolfo Dirzo7, Elisabeth Huber-Sanwald8, Laura F. Huenneke9, Robert B. Jackson10, Ann Kinzig11, Rik Leemans12, David M. Lodge13, Harold A. Mooney14, Martín , 2000). Nitrogen and phosphorus are the most important minerals for the growth and development of non-vascular plants (Vitousek and Howarth, 1991).

(Vellak and Paal, 1999) state that it is the most sensitive indicators for evaluating human impacts in forests. Many species of it survive only in forests without large human impacts (Cooper-Ellis, 1998).

In terms of ecological aspects, it has various uses, they are:

(1) Pioneer plant in barren areas that is nutrient-poor by forming a colossus of bryophyte (carpet of bryophyte) on the surface of the soil that allows organic layers to form and helps the growth of microorganisms. Microbes will change organic matter (minerals) and nutrients at the surface of the soil so that the soil becomes fertile and can be overgrown by other plants.

(2) Pollution and Heavy Metal Indicators. bryophyte is an air bioindicator, water pollution, and heavy metal accumulator. The size of true moss, lichen, and liverwort will decrease during the process of pollution. bryophyte will decrease even disappear in polluted areas such as some tolerant species, namely, Bryum, Ceratodon, Dicranoweisia, Funaria, Hyophila and Tortula. The genera Pylaisiella and Orthotrichum as bioindicators of hydrogran fluoride (HF) pollution are indicated by changes in leaf color due to chlorophyll degeneration (Rao, 2011). Sphagnum has a special character for binding radioactive compounds through cation exchange and it is also used to purify wastewater contamination. Some species of Anomodon, Dicranum, Eurhynchium, Leucodon, Mnium, Rhynchostegium and Thuidium can accumulate cesium. Brachythecium, Buxbaumia and Grimmia species are able to concentrate many of the strontium found in their living areas. Some terrestrial bryophyte can accumulate uranium. Bryum, Dicranella and Polytrichum species are able to tolerate high levels of zinc, cadmium, and copper in their tissues. 
(3) Bryophyte is as an indicator and has a great ability to retain some minerals in the substratum compared to vascular plants. It is used for a tool for geobotany studies because some types of them like living places that have high minerals. Barbula, Gymnocolea, Merceya, Mielichhoferia, Scopelophila, and Solenostoma species prefer to grow on substrates with high concentrations of copper, zinc, iron and lead (in the form of sulfides). The genera Campylopus, Barbula, Brachythecium, Bryum and Gymnostomum are known to grow on gypsum (pH 4.9-7.8) (S.D. Tiwari, 2002). Moreover, it grows in a very sharp ecological range and it is also as an indicator of good environmental conditions, and soil quality. Some types of them is as an indicator of acid soils such as Polytrichum, Atrichum undulatum, Marchantia polymorpha, Tortula rhyzophylla (Taoda, 1977).

\subsection{New Record and New Species}

Researches in the diversity of species of bryophytes, such as liverwort, true moss, or hornwort have been started since 1884 until now (Sande-Lacoste 1884; Herzog 1943; Gradstein et al., 2005; Schafer-Verwimp 2006; Soderstrom et al., 2010; Gradstein, 2011; Siregar 2015; Nunik, 2018; Lee et al., 2019). Previous researches aim to gather the information about the diversity of bryophyte species of in various regions included in the Malesia region.

The results obtained from research activities in the Malesia region on flora included new records and new species. (Ariyanti et al., 2009) reported specifically for lichens in Sulawesi, there were 177 species of lichens which was a new record for Sulawesi consists of 61 species of true lichen, 115 types of liverwort, and 1 type of lichen. The total species of mosses in Sulawesi were 653 species.

The report of (Tan, Shevock and Coritico, 2015) was very useful especially for the Philippines region because 20 species of true moss were found which were new records for Mindanao Island which 5 of them were new records for true Philippine moss, and the Metadistichophyllum species was a new genetic record for Philippine flora. From the notes of the 5 additional species above, Chaetomitrium ciliatum, Distichophyllum subcarinatum, Hampeella pallens and Metadistichophyllum rhizophorum reveal the existence of the floristic relationship of Mindanao Island with Kalimantan, Java and Australasia. In 2016 in the Enggano Island area Bengkulu obtained 2 clans as a new record for Sumatra, namely Gongylanthus, and Symphyogyna (Nadhifah and Surya, 2016).

The most recent record of moss species for the Borneo region was reported by (Suleiman, Masundang and Akiyama, 2017) 6 species, namely Barbella horridula, Chaetomitrium lancifolium, Distichophyllum leiopogon, Rhaphidostichum luzonense, Rosulabryum capillare and Taxiphyllum taxirameum. Furthermore, in 2018 there were 2 types of Fissidentaceae, namely $F$. bogoriensis and $F$. braunii which are the new records for Borneo (Sarah Agustiorini, 2018). The results of data searches conducted (Gaik Ee Lee, Ahmad Damanhuri, 2019) in Terengganu in 2019 found 257 species of moss with 6 species being endemic to Terengganu. Ten species that were originally rare moss and were only recorded in Pahang and Kedah, were found in Terengganu. These research results also showed that there were 3 types as new records for Peninsular Malaysia and 11 types of new records for Terengganu.

\section{Conclusion}

Bryophyte is a non-vascular plant that plays an important role in tropical forest ecosystems. The ability of it is to form fertile ecosystems from nutrient-poor conditions, 
places and it is as pioneering plant in ecosystems in order to help the development and growth of other vegetation. In addition, it functions ecologically as a bioindicator of pollution, a clean environment, and economically as an ornamental plant and medicine proves the importance of it. The diversity of species of them consists of liverwort, true moss, and hornwort, especially in the area of Malesia included Indonesia as a source of germplasm that must be preserved. Indonesia is as a tropical region and included in the ranks of countries with high plant diversities, a paradise for moss researchers to explore the diversity of species of them. It is hoped that the various studies and discoveries (new records and new species) related to this flora will provide accurate information on the diversity of species of bryophytes in Malesia.

\section{References}

Alpert, P. (1991) 'Microtopography as habitat structure for mosses on rocks', Springer, pp. $120-140$.

Ariyanti, N. S. et al. (2009) 'Catalogue of the bryophytes of Sulawesi. Supplement 1: New species records', Blumea: Journal of Plant Taxonomy and Plant Geography, 54(1-3), pp. 287-289. doi: 10.3767/000651909X476300.

Batty, K., J. W. Bates, and J. N. B. (2003) 'A transplant experiment on the factors preventing lichen colonization of oak bark in southeast England under declining SO pollution', Canadian Journal of Botany, 81(5), pp. 439-451. doi: 10.1139/b03-039.

Brummitt, R. K. (2001) World Geographical Scheme for Recording Plant Distributions. Available at: http://www.tdwg.org/standards/109.

Budke, J. M. et al. (2018) 'Introduction to the Special Issue on Bryophytes', Critical Reviews in Plant Sciences. Taylor \& Francis, 37(2-3), pp. 102-112. doi: 10.1080/07352689.2018.1482396.

Cole, T. C. H. and Hilger, H. H. (2016) 'Bryophyte Phylogeny Poster', p. 1.

Cooper-Ellis, S. (1998) 'Bryophytes in old-growth forests of western Massachusetts.', Journal of the Torrey Botanical Society, 125(2), pp. 117-132.

Dey, A. and Nath De, J. (2011) 'Antifungal bryophytes: A possible role against human pathogens and in plant protection', Research Journal of Botany, pp. 129-140. doi: 10.3923/rjb.2011.129.140.

Dymytrova, L. (2009) 'Epiphytic lichens and bryophytes as indicators of air pollution in Kyiv city (Ukraine)', Folia Cryptogamica Estonica, 46(January 2009), pp. 33-43.

Gaik Ee Lee, Ahmad Damanhuri, and N. N. (2019) 'Diversity of bryophytes of Terengganu and their ecological roles in the environment', Springer, pp. 53-66.

Gairola, S., Semwal, D. P. and Uniyal, P. L. (2014) ‘Bryophytes and Ecosystem', (June).

Govindapyari, H. et al. (2010) 'Bryophytes: indicators and monitoring agents of pollution', NeBIO, 1(1), pp. 35-41.

Gradstein, S. R., Churchcill and Salazar, A. (2009) 'Morphology of Bryophytes. A Handout Lecture of Regional Training Course on Biodiversity Conservation of Bryophytes and Lichens.', in handout. Bogor.

Groombridge, Brian, Martin D. Jenkins, and M. J. (2002) No Title World atlas of biodiversity: earth's living resources in the 21st century. london: Univ of California Press.

Ludwiczuk, Agnieszka, and Y. A. (2008) 'Distribution of terpenoids and aromatic compounds in selected Southern Hemispheric Liverworts.', Fieldiana Botany, 4(5), pp. $37-58$ Available at: https://www.researchgate.net/publication/286881419_Distribution_of_terpenoids_and_ aromatic_compounds_in_New_Zealand_liverworts. 
Budapest International Research in Exact Sciences (BirEx) Journal Volume 2, No 1, January 2020, Page: 106-112 e-ISSN: 2655-7827 (Online), p-ISSN: 2655-7835(Print) www.bircu-journal.com/index.php/birex emails:birex.journal@gmail.com birex.journal.qa@gmail.com

Nadhifah, A. and Surya, M. I. (2016) 'A Preliminary Study of Bryophytes in Enggano Island, Bengkulu, Indonesia', Biosaintifika: Journal of Biology \& Biology Education, 8(2), p. 201. doi: 10.15294/biosaintifika.v8i2.5239.

Osvaldo E. Sala1,*, F. Stuart Chapin , III2, Juan J. Armesto4, Eric Berlow5, Janine Bloomfield6, Rodolfo Dirzo7, Elisabeth Huber-Sanwald8, Laura F. Huenneke9, Robert B. Jackson10, Ann Kinzig11, Rik Leemans12, David M. Lodge13, Harold A. Mooney14, Martín, D. H. W. (2000) 'Global Biodiversity Scenarios for the Year 2100', Science, 287(5459), pp. 1770-1774. doi: 10.1126/science.287.5459.1770.

Rao, F. L. C. N. (2011) 'Fluoride injury symptoms in epiphytic lichens and mosses', Canadian Journal of Botany, 49(9), pp. 1691-1698. doi: 10.1139/b71-238.

S.D. Tiwari, G. B. P. (2002) Bryophytes Of Kumaun Himalaya. Bishen Singh Mahendra Pal Singh.

Sarah Agustiorini, N. S. A. (2018) 'REKAMAN BARU FISSIDENS (BRYOPHYTA: FISSIDENTACEAE) UNTUK BORNEO', Floribunda, 6(1).

Shaw, J. and Renzaglia, K. (2004) 'Phylogeny and diversification of bryophytes', American Journal of Botany, 91(10), pp. 1557-1581. doi: 10.3732/ajb.91.10.1557.

Sheffield, L. (2001) 'Shaw AJ, Goffinet B, eds. 2000. Bryophyte biology. 476pp. Cambridge: Cambridge University Press. $£ 22.95$ (softback).', Annals of Botany, 87(5), pp. 703-704. doi: 10.1006/anbo.2001.1376.

Shen, J. et al. (2010) 'Marchantin C: A potential anti-invasion agent in glioma cells', Cancer Biology and Therapy, 9(1). doi: 10.4161/cbt.9.1.10279.

Sillett, S. C. and Neitlich, P. N. (1996) 'Emerging themes in epiphyte research in westside forests with special reference to cyanolichens', Northwest Science, 70(SPEC. ISS.), pp. $54-60$.

Sing, D. K. (2001) 'Diversity in Indian liverworts: their status, vulnerability and conservation.', Perspectives in Indian Bryology, pp. 325-354.

Suleiman, M., Masundang, D. P. and Akiyama, H. (2017) 'The Mosses of Crocker Range Park , Malaysian Borneo', 107, pp. 71-107. doi: 10.3897/phytokeys.88.14674.

Sveinbjörnsson, B., and W. C. O. (1992) Bryophytes and lichens in a changing environment. Edited by J. W. B. and A. M. Farmer. New York; London: Clarendon Press; New York: Oxford University Pres.

Tan, B., Shevock, J. and Coritico, F. (2015) 'Mosses new for Mindanao Island, the Philippines(3)', Bulletin of the National Museum of Nature and Science. Series B, Botany, 41(3), pp. 91-97.

Taoda (1977) 'Bryophytes of urban ecosystem. In: Numata M. (Ed.)', in. Tokyo, Japan.

Vellak, K. and Paal, J. (1999) 'Diversity of bryophyte vegetation in some forest types in Estonia: A comparison of old unmanaged and managed forests', (May 2014). doi: 10.1023/A.

Vitousek, P. M. and Howarth, R. W. (1991) 'Nitrogen limitation on land and in the sea: How can it occur?', Biogeochemistry, 13(2), pp. 87-115. doi: 10.1007/BF00002772.

Xie, Chun-Feng, and H.-X. Lou (2009) 'Secondary metabolites in bryophytes: an ecological aspect.', Chemistry \& biodiversity, 6(3), pp. 303-312. Available at: https://doi.org/10.1002/cbdv.200700450. 